\title{
Forest Research Advisory Council of Canada Annual Report for 1989 \\ March 9, 1990
}

\section{Summary}

The Forest Research Advisory Council provides advice to Forestry Canada (FC) on national forest research priorities and policies. This report covers the 1989 calendar year at the close of which Mr J.C. Wright stepped down from the Chairmanship and was succeeded by Mr J.W. Toovey.

A major accomplishment during the year was the preparation, with the assistance and cooperation of the provincial and territorial forest research advisory bodies, of a national overview of forest research priorities and concerns. This overview report appeared in the December 1988 issue of the Forestry Chronicle published by the Canadian Institute of Forestry and in addition was sent to some 400 recipients across the country. Four general subject areas were identified for priority attention namely managing the forest as an integrated ecosystem; renewing the forest; protecting the forest; and producing improved products from the "new forest". Technology transfer was recognized universally as a very high priority.

The Catalogue of Forest Related Research initiated at FRACC's suggestion and compiled by Dr. A.J. Kayll was reviewed and tested with the conclusion that the project is worthwhile and should be continued with refinements.

Council recommends (1) - that Forestry Canada provide for the continuation of the Catalogue of Forest Related Research and make it available to all contributors and Forestry Canada units asking them to use it and to comment upon it with the view of making further improvements.

Council requested a set of summary tables depicting Forestry Canada's research work and found these data most useful.

Council recommends (2) - that Forestry Canada prepare annually a set of summary tables showing research projects and budgets by program area at all FC establishments including Headquarters to enable the program to be readily understood and tracked over time. Headings should correspond with those used in the Forestry Canada Research Planning Guidelines. Consideration should be given to using graphics to show program elements and how they change over time.

In its review of FC research, Council found some differences in program documentation across the country.

Council recommends (3) - that Forestry Canada take immediate steps to make program documentation consistent across the country and ensure that the documentation for each project includes a brief statement of the forestry problem, as distinct from and in addition to, the scientific problem being addressed.

In view of the importance of collaboration and cooperation in research,

Council recommends (4) - that Forestry Canada must ensure that all collaborative opportunities are explored thoroughly when it is both planning and executing its research.

The involvement of industry in the planning and conduct of research is of great importance. In 1989 Council continued its exploration of the tax treatment afforded industry "assistance in kind" to research. As a small step to improve industry input,

Council recommends (5) - that Forestry Canada ensure that all groups set up to provide advice directly to the various FC units include suitable representatives from the forest industry.

In its work program for 1990 Council will:

1. Identify emerging research priorities both regional and national and in particular obtain input from the non-timber oriented forest stakeholders in order to better understand the forces shaping future demands on the forest and thus affecting research needs and priorities.

2. Monitor trends in Forestry Canada research funding and make appropriate recommendations.

3. Continue to work with the provincial and territorial research advisory bodies to assemble a national overview of forest research priorities for the Canadian Council of Forest Ministers.

4. Develop a more organized format for Council's visits to $\mathrm{FC}$ establishments to enable a better review of the mission statements of both Forestry Canada as a whole and the FC research establishments. Particular attention will be given to the working relations between institutes and regional centres and also between centres.

5. Continue efforts to devise means to increase industry involvement in forestry research and follow up on work undertaken to date concerning the tax treatment of research.

6. Consider the research components of the FRDA's and how these can be managed to be responsive to local needs and at the same time contribute to broader concerns such as the ability of the forest to produce a sustainable flow of all benefits including, but not limited to, recreation, timber, wilderness, fur, water, and climate.

7. Examine the factors affecting the supply of young scientists and the ingredients that make for a productive research climate.

\section{Introduction}

The Forestry Research Advisory Council of Canada (FRACC) was created in 1983 to advise Forestry Canada (formerly the Canadian Forestry Service) on forestry research priorities and policies at the national level. In 1987, Council's role was expanded. It became responsible for preparing, with 
the close cooperation and assistance of the provincial and territorial forest research advisory bodies, an annual national overview of research priorities and concerns for the Canadian Council of Forest Ministers (CCFM).

This report covers calendar 1989. Members of the Council for the period are listed in Appendix 1. During the year, the Council held four meetings (Appendix II) and provided comments and advice to the Deputy Minister, Forestry Canada on several research related issues. For the first time in 1989, Council met jointly with the Forestry Canada Committee of Research Establishments (CORE) at St John's Newfoundland where the two groups reviewed the program of the Newfoundland Region. This Committee is made up of the senior research managers from each Forestry Canada establishment and representatives from the Science Directorate in Ottawa. This joint meeting provided a useful opportunity for FC research managers to become aquainted with members of FRACC and to hear of their concerns.

In addition to its project to summarize research priorities across the country, Council in 1989 reviewed Forestry Canada research documentation methods for the program as a whole and examined in detail the research programs at the Petawawa National Forestry Institute and the Newfoundland Region.

\section{Research Priorities Across Canada}

In 1987, Council proposed an annual national survey of research priorities and emerging concerns for the Canadian Council of Forest Ministers (CCFM). This was agreed to by CCFM as a means to improve dialogue and research coordination and in 1989 the forest research advisory bodies in each province and territory cooperated with FRACC to prepare a report summarizing forest research priorities across Canada. The report entitled "Forest Research Priorities in Canada, An Overview for the Canadian Council of Forest Ministers" was presented to the CCFM at its meeting in October at Niagara Falls, Ontario by a representative of Council. The report was published in the December 1989 issue of the Forestry Chronicle and in addition mailed to some 400 recipients.

The report pointed out that the aim of forest research, as agreed to by most correspondents, is to develop environmentally sound integrated forest land management systems that will improve the sustainable supply of economic timber and fibre, and enhance other benefits particularly recreation opportunities and habitat for fish and wildlife.

Four general areas were identified for priority research attention; 1) Managing the forest as a integrated ecosystem; 2) Renewing the forest; 3) Protecting the forest; and 4) Producing improved products from the "new forest". These are elaborated below. In addition, improving technology transfer was universally recognized as very high priority.

Research Priorities for Integrated Management:

(a) Integrated forest land management systems with comprehensive information systems coupled with biological and economic decision criteria.

(b) Growth and yield data for managed stands and related topics.

(c) Defining wildlife habitat requirements.

(d) Long-term effects of various timber harvesting systems on the forest ecosystem.

(e) Atmospheric pollutants and forest ecosystem functioning.
Research Priorities for Renewing the Forest:

(a) Regeneration systems and competing vegetation management.

(b) Biotechnology and speedier tree improvement systems.

(c) Plantation establishment and planting stock quality.

(d) Tending the "new forest" for greater yield.

Research Priorities for Protecting the Forest:

(a) Alternatives to chemicals for pest control.

(b) Wildfire prediction and control.

(c) Risk assessment and management.

(d) Pesticide registration

(e) Integrated fire management systems.

Research Priorities for Improved Products from the "New Forest":

(a) Assessing the properties of wood from the "new forest"

(b) Developing new and more efficient manufacturing methods.

(c) New product development.

There was less unanimity about issues that will affect research priorities in the future. All groups placed great emphasis on the importance of a properly informed public. The following issues were identified as important:

(a) Increasing concern by the public and the forestry profession about the use of herbicides and pesticides.

(b) Concern whether regenerated stands will hold up long term.

(c) Concern about the long term federal committment to forestry.

(d) Fear that sustained base-funding for research may be jeopardized by excessive reliance on FRDA research funds.

(e) Gains possible from intensifying management on prime sites.

(f) The opportunity presented by underutilized hardwood species.

(g) The potential for growing quality hardwoods and concern about their present low availability.

It was reported that research advisory structures were in place in all jurisdictions and all have, or soon will have, industry input. Current research programs were considered scientifically and technically sound but additional funding and some re-direction and improved co-ordination is needed to improve effectiveness.

\section{Actions Stemming From Council's 1988 Report}

In 1988 Council recommended that Forestry Canada should continue to provide a brief annual, year-end communication to FRACC providing in point form, information on actions taken on recommendations made by FRACC at the close of the previous year. This was agreed to by Forestry Canada and the statement covering steps taken on FRACC's 1988 recommendations is attached as III.

\section{Terms of Reference and FRACC Operations}

Council reviewed the status of the Canadian Pulp and Paper Association (CPPA) representative and recommended that the ex officio designation be dropped and the CPPA representative be made a full member of Council. This 
was agreed to and made effective for the August meeting of FRACC.

At Council's last meeting in 1988 the possibility of expanding FRACC to include a representative from the forestry profession was discussed. Accordingly, early in 1989 it was recommended that the Canadian Institute of Forestry be invited to name a representative to FRACC. This was agreed to and The Institute subsequently named Mr William J. Brown of Huntsville, Ontario as its representative.

Mr. Jack C. Wright completed his term as Council Chairman at the close of 1989 and the Deputy Minister, Mr. Mercier, was pleased to announce that Mr Jack W. Toovey had agreed to assume the Chair. Council recommended that a new position of past chairperson be created to provide continuity. This was agreed to by Mr. Mercier. The terms of reference have been revised to reflect these changes and are attached as Appendix IV.

\section{Catalogue of Forest Related Research Activities}

In 1987, Dr. A.J. Kayll of the School of Forestry at Lakehead University spent a year at Forestry Canada headquarters in Ottawa working on a special assignment to set up a readily revisable national catalogue of forest and forestrelated research. This was in response to suggestions by FRACC that such an inventory would be useful to those performing and utilizing research in forestry including those responsible for setting policy and priorities.

Dr. Kayll set 1985-86 as his base year and gathered information on over 1000 studies being conducted in the field and laboratory by universities, government agencies and industry. A computer data base was created that makes it possible to extract information in a variety of ways, for example by tree species, by region, by technical subject, etc. Dr. Kayll's final report was presented to FRACC and Forestry Canada in the summer of 1988.

On receiving the report, FRACC created a small sub-committee to examine the data base design, suggest improvements and means for updating the information. This Committee reported in March 1989. It found that a good start had been made in setting up a system for a continuing inventory of forest research in Canada. Some problems were identified in using the data base but it was concluded that these could be remedied through additional programming to make the system more "user friendly" and some suggestions were made to this end. The overall conclusion of the subcommittee was that the project was very worthwhile and should continue with refinements. Council as a whole endorsed this view.

Recommendation 1 - Forestry Canada should provide for the continuation of the Catalogue of Forest Science and make it available to all contributors and Forestry Canada units asking them to use it and to comment upon it with the view of making further improvements.

\section{Program and Program Documentation}

In 1989, Council heard a presentation by Dr. Graham Page on Forestry Canada's evolving research program documentation system and received, in response to its request, a set of tables summarizing the research programs and budgets at all FC establishments. These tables proved very useful to Council and to FC senior management as well in that they gave an easily understood overview of the research program.

Recommendation 2 - Forestry Canada should prepare annually a set of summary tables showing research projects and budgets by program area at all FC establishments including headquarters to enable the program to be readily understood and tracked over time. Headings should correspond with those used in the Forestry Canada Research Planning Guidelines. Consideration should be given to using graphics to show program elements and how they change over time.

Council also reviewed in some detail the research programs being conducted at the Petawawa National Forestry Institute and the Newfoundland Region. While it is not Council's role to conduct detailed reviews of the research at all Forestry Canada establishments, periodic examination of selected segments of the program gives the opportunity for Council to understand and comment on current Forestry Canada research management concepts and to maintain familiarity with the program.

The research at The Newfoundland Forestry Centre was considered generally to be well in tune with local requirements in Newfoundland where the vast majority of research is conducted by Forestry Canada. Council was particularly pleased to see that the Region had prepared a mission statement. The Petawawa program was considered properly responsive to national needs in such specialized areas as biotechnology, expert systems, fire management systems, tree improvement and growth and yield.

After these examinations and presentations, Council noted that not all FC units had prepared mission statements and that there is a noticeable lack of uniformity in the ways the various units are documenting their programs. This makes the program more difficult to understand and it was felt that this must hamper the ability of FC to manage and defend its research program. Council is of the opinion that poorly understood programs are often subject to unwarranted and hostile criticism.

Recommendation 3 - Forestry Canada should take immediate steps to make program documentation consistent across the country and ensure that the documentation for each project includes a brief statement of the forestry problem, as distinct from and in addition to, the scientific problem being addressed.

Council also made note of the fact that program documentation did not always identify potential or actual collaborators or activities by other agencies that would assist or amplify the impact of the FC work. Specific reference was made to Forintek. FERIC, PPRIC and the universities.

Recommendation 4 - Forestry Canada must ensure that collaborative opportunities are explored thoroughly when it is both planning and executing its research.

\section{Industry Involvement in Forest Management Research}

In studying the Forestry Canada research program and its management in 1988, Council was cognizant of the ongoing need to involve the forest industry in the planning and execution of forestry research. It recognizes that industry input is affected by a host of factors, many of which are beyond the influence of Forestry Canada. However the need 
to have adequate industry input to the bodies that provide forestry and forestry research advice directly to the FC units is sometimes overlooked.

Recommendation 5 - Forestry Canada should ensure that all groups set up to provide advice directly to the various FC units include suitable representatives from the forest industry.

In 1988 Council recommended that Forestry Canada should work with Revenue Canada to ensure that industry participants offering "assistance in kind" to research programs are fully eligible for favourable tax treatment for such research. This question was given further consideration by Council in 1989 and discussions were held between representatives of Revenue Canada and Council. Two case studies representing examples of industry "in kind" input were submitted to Revenue Canada for study and comment. Further study and discussions are planned for 1990.

\section{Plan of Action for 1990}

Council will focus on the following areas in 1990:

1. Identify emerging research priorities both regional and national and in particular obtain input from the non-timber oriented forest stakeholders in order to better understand the forces shaping future demands on the forest and thus affecting research needs and priorities.
2. Monitor trends in Forestry Canada research funding and make appropriate recommendations.

3. Continue to work with the provincial and territorial research advisory bodies to assemble a national overview of forest research priorities for the Canadian Council of Forest Ministers.

4. Develop a more organized format for Council's visits to FC establishments to enable a better review of the mission statements of both Forestry Canada as a whole and the FC research establishments. Particular attention will be given to the working relations between institutes and regional centres and also between centres.

5. Continue efforts to devise means to increase industry involvement in forestry research and follow up on work undertaken to date concerning the tax treatment of research.

6. Consider the research components of the FRDA's and how these can be managed to be responsive to local needs and at the same time contribute to broader concerns such as the ability of the forest to produce a sustainable flow of all benefits including, but not limited to, recreation, timber, wilderness, fur, water, and climate.

7. Examine the factors affecting the supply of young scientists and the ingredients that make for a productive research climate.

\section{Appendix 1 \\ FRACC Membership for 1989}

\section{Provincial Representation}

Mr. John R. Cuthbert, Chief Forester, Tel: 604-387-1296

Government of British Columbia,

595 Pandora Ave.

Victoria, British Columbia,

V8W 3E7.

Mr. C. David Rannard, Director,

Forestry Branch,

Department of Natural Resources

300-530 Kenaston Blvd.,

Winnipeg, Manitoba,

R3N 1 Z4.

Mr. John Goodman, Executive Director Tel: 705-945-6680

Forest Resources Group,

Ministry of Natural Resources,

Fax: 705-945-9450

258 Queen Street East, PO Box 1000,

Sault Ste Marie, Ontario,

P6A 5N5.

Mr. Robert D. Mercer

Director of Forest Management,

Department of Forest Resources and Lands,

PO Box 2002,

Cornerbrook, Newfoundland,

A2H $6 J 8$.

Mr. Claude Godbout, Directeur,

Direction de recherche et de développement,

Tel: $204-945-7998$

Fax: 204-489-1360

Fax: 604-387-6267

Complexe scientifique,

2700 rue Einstein,

Ste-Foy, Québec,

G1R 3W8

(Mr. Godbout was a member of Council in the above capacity until August 1989 when he was appointed Dean of Forestry at the University of Laval. He has been appointed as a member at large for 1990.)

\section{Industrial Representation}

Mr. Bernard W. Burgess,

Hillcrest Road,

Tel: $613-345-2285$

R.R. \#3 416-488-5262

Brockville, Ontario,

K6V 5T3.

M. Jean Paquet

Chef forestier, Domaine forestier

Tel: $514-875-2160$

Stone Consolidated Inc.

Fax: 514-875-6284

800 Boul. Réne Levesque Ouest,

Montreal, Quebec,

H3B 1 Y9.

Tel: $709-637-2344$

Fax: 709-637-2403

Mr. Jack W. Toovey, RPF

Tel: 604-654-6194

Vice President, Timberlands \& Forestry, Fax: 604-654-4394

Fletcher Challenge Canada,

9th floor, 700 West Georgia St,

P.O. Box 10058, Pacific Centre

Vancouver, B.C.

V7Y $1 \mathrm{C} 2$.

Tel: 418-643-7995

Fax: 418-643-2165
Tel: $403-865-2729$

Fax: 403-865-8129
Mr. Jack C. Wright, (Chairman)

107 Simpson St.,

Hinton, Alberta,

T7V $1 \mathrm{C} 2$.

Ministère de l'énergie et des ressources, 


\section{Canadian Institute of Forestry Representation}

Mr. William J. Brown

General Manager,

Algonquin Forestry Authority,

222 Main Street,

Huntsville, Ontario,

POA $1 \mathrm{KO}$.

\section{University Representation}

Dr. Peter J. Murphy,

Associate Dean (Forestry),

Faculty of Agriculture \& Forestry

214 Agriculture/Forestry Building,

University of Alberta,

Edmonton, Alberta,

T6G 2 P5.

Dr. Gilles Frisque, Director

Multiregional Forest Research Centre,

University of Quebec,

3rd Floor, 2875 Boulevard Laurier,

Sainte Foy, Quebec,

G1V $2 M 3$
Tel: $705-789-9647$

Tel: $403-492-1360$

\section{Tel: 418-657-3551 Executive Secretary}

Dr. R.J. Bourchier

R.R. \#1, P.O. Box 255,

Cantley, Quebec,

JOX 1 LO
Tel: 514-866-6621

Fax: 514-866-3035
(1155 Metcalfe Street,

H3B 4 T6.

\section{Ex Officio}

Dr. Fred C. Pollett, Director General,

: 819-997-1107

. Joseph,

Hull, Quebec,

K1A 1 G5.

Fax: 613-990-3437

\section{Appendix II \\ FRACC Meetings 1983-1989}
1. Toronto
2. Montreal
3. Vancouver
4. Ottawa
5. Fredericton*
6. Edmonton*
7. Sault St Marie*
8. Victoria*
9. Quebec*
10. Ottawa
11. Vancouver

\author{
November 10, 1983. \\ January 29-30, 1984. \\ June 19-20, 1984. \\ November 7-8, 1984. \\ February 7-8, 1985. \\ July 30-31, 1985. \\ October 29-30, 1985. \\ May 5-6, 1986. \\ August 12-13, 1986. \\ November 13-14, 1986. \\ March 11-12, 1987.
}

\section{Quebec}

13. Ottawa

14. Toronto

15. Ottawa

16. Hull

17. Ottawa

18. Petawawa*

19. St John's*

20. Kananaskis

* Held at Forestry Canada Establishments

\section{Appendix III}

\section{FRACC Recommendations - 1988}

Recommendation 1. Forestry Canada should continue to provide a very brief annual, year-end communication to FRACC, providing in point form, information on actions taken on FRACC recommendations made at the close of the previous year.

\section{FC Response. FC accepts the recommendation.}

Action. FC has been providing an annual action report to FRACC since 1987 and will continue to do so.

Recommendation 2. Considering the broadly based support for the Action plan stemming from the 1988 national forestry research forum in Edmonton, Forestry Canada must ensure that the recommendations are implemented in the Forestry Canada program.

FC Response. FC agrees with this recommendation, and will implement the findings of the 1988 Edmonton Forum wherever possible in its program.

Action. FC has taken a number of steps to implement Forum recommendations where these fall within its juris- diction. In particular, the Department has reaffirmed its commitment to, and its lead role in forestry S\&T; redefined its S\&T priorities to focus more strongly on a smaller number of issues of critical importance to the forest sector during the next decade; continued its research on pinewood nematode, codes and standards, and other areas related to non-tariff barriers to trade; continued to strongly support and actively participate in multi-agency forest research advisory bodies, which are now in place in most jurisdictions across the country; increased its support for university forestry research, in cooperation with NSERC and industry; expanded its efforts to involve industry in joint S\&T programs through networking and participation in the federal Technology Centres Program; and introduced a number of measures to enhance public awareness of forest research and its benefits. Some of these initiatives are described more fully below in response to other recommendations by FRACC.

Recommendation 3. Forestry Canada should encourage and strengthen forest resources oriented activities of the Forest Sector Advisory Council and by using research advisory structures increase that Council's understanding of the importance of forest resources research. 


\section{FC Response. FC agrees with this recommendation.}

Action. Forestry Canada has established a Forest Sector Advisory Council Sub-committee on Forestry. The work of this sub-committee would serve industrial planning discussions in FSAC and be a basis on which to develop recommendations to the CCFM through the Minister of Forestry with respect to forest management. Such an approach could have a major influence on the focus of forest management initiatives in Canada.

Recommendation 4. Forestry Canada should ensure that in negotiating the next generation of forestry agreements, due attention is paid to planning and executing the very important research components so that they are clearly recognized and planned and managed to ensure the information produced is readily available across the country.

FC Response. FC agrees and will be emphasizing the need for an enhanced research component during negotiations for the next round of federal-provincial forestry agreements.

Action. A significantly expanded applied research component has been incorporated into the agreements with New Brunswick and Nova Scotia that have just been signed. A similar R\&D component will be required by federal negotiators as new agreements are finalized with other provinces. In the negotiation process, federal representatives are utilizing information on national and regional forestry research priorities as identified by advisory committees and by Forestry Canada through its strategic planning process.

Recommendation 5. Forestry Canada should intensify its efforts to disseminate research findings from all sources through joint sponsorship of seminars and workshops.

FC Response. FC agrees and will be increasing its efforts to publicize and disseminate its research findings by various means.

Action. Forestry Canada has participated actively in the forestry research "Carrefours" held in Quebec, and in the Forestry Research Marketplace in Ontario in 1989. A series of advertisements on forestry research has been initiated, a symposium on "Advances in Forestry Research in Canada" has been held, and plans are underway for publication of a new series of annual reports on accomplishments in research. In addition, ongoing technology transfer activities are being strengthened wherever possible through development agreements and regular research program activities; examples include Silvilog and national GIS conferences.

Recommendation 6. Council recommends that Forestry Canada continue to seek innovative means to foster an enhanced and sustained input to forest management research by the forestbased industry.

FC Response. FC fully supports this recommendation and will do whatever it can to encourage greater private sector input to forestry research.

Action. A new Forestry Canada/NSERC Partnerships program has just been put in place. This program will provide an additional $\$ 1$ million support for university forestry research in Canada in 1990/91, but only for projects to which industry or other client agencies have made a prior commitment of financial support. Preliminary indications are that the program will be successful in levering a significantly enhanced level of industrial support for forestry research.

Recently, Forestry Canada has reaffirmed its participation in the federal Technology Centres Policy. This policy is designed to encourage greater private sector support for S\&T programs at federal laboratories and an increased level of joint research between government and industry. All Forestry Canada laboratories are being urged to expand and formalize cooperative arrangements with other agencies so as to increase both cash and in-kind support from external sources and enhance the possibilities of earning bonus payments which will be directed into the research program.

Forestry Canada is actively promoting a number of networking arrangements, both nationally and internationally, to enhance cooperation among forestry research agencies and obtain increased support for high priority forestry research topics from the private sector. Forestry Canada is participating, with other government agencies, industry and universities, in several networks in the fields of biotechnology and pest control.

Recommendation 7. Forestry Canada should encourage the use of industry "assistance in kind" by working with Revenue Canada to ensure that industry participants in such programs are fully eligible for favourable tax treatment for such research.

FC Response. Forestry Canada has been working with FRACC in preparing a series of case studies that could be assessed by Revenue Canada to clarify problems of eligibility for tax preference.

Recommendation 8. Forestry Canada should try to mitigate the potential negative effects of the Canadian Environmental Protection Act and its regulations on forest research.

FC Response. Forestry Canada understands that there is concern in some parts of the forest sector about the possible negative effects on forestry operations of the Environmental Protection Act and the Environmental Assessment and Review Process (EARP). However, the Department believes that the provisions of this Act are necessary for the protection of all Canadians and that the Act presents no threat to sound forestry practices.

Action. Forestry Canada is one of a number of federal agencies that are working with Environment Canada on revisions to the EARP process, so as to ensure that the legitimate concerns and needs of forestry and other resource sectors are fully taken into account.

Forestry Canada's S\&T program is emphasizing several priority areas which will assist the forest sector in meeting high environmental standards in its day-to-day operations. The most significant of these research programs are those concerned with developing biological methods as an alternative to chemicals for control of insects, disease and weeds, applying biotechnology in the forest products industry to reduce the production of environmentally damaging waste materials, and developing decision support systems that will permit forest managers to more successfully integrate consumptive and non-consumptive forest uses.

Recommendation 9. Forestry Canada must continue to press the federal Treasury Board for a significant increase in its base funding for the operation of its research program. 
Funding from Forest Resource Development Agreements should be considered incremental to the base funding of the Forestry Canada program.

FC Response. Forestry Canada is in full agreement with this recommendation, and will do whatever it can to increase support for research through base program and development agreement mechanisms.

Action. Forestry Canada made a special submission to Treasury Board for additional support for its base research program. This submission was successful and has resulted in additional funding for the Department of $\$ 2.5$ million in $1989 / 90$ and $\$ 5.0$ million in 1990/91 and subsequent years, specifically for S\&T purposes. These new funds are being used to strengthen several in-house programs in high priority fields, and to initiate new activities designed to support university research and joint projects with client agencies.

In addition, a strengthened R\&D component is being built into all new federal-provincial forestry development agreements (see also response to Recommendation \#4).

Recommendation 10. Council agrees with the general tenor and thrust of the recently approved Forest Insect and Disease Survey Strategic Plan that provides for a shift away from routine surveys to research, but recommends that Forestry Canada maintain and enhance its leadership in conducting workshops and technology transfer seminars on specific pest problems.

FC Response. Forestry Canada accepts this recommendation and will continue to participate actively in technology transfer activities relating to forest pests.

Action. The provisions of the Forest Insect \& Disease Survey (FIDS) Strategic Plan are gradually being put in place as circumstances in individual provinces permit. However, even in those instances where a province has assumed all or most of the responsibility for routine surveys, the FIDS units are maintaining a leadership role in survey methodology, new pest problems, interprovincial and international pest issues, advice to pest control organisations, and short-term applied research.

Recommendation 11. Forestry Canada should expedite completion of its planning document for biotechnology research. Forestry Canada must be able to collaborate actively in this important research area.

FC Response. Forestry Canada agrees and will be addressing this as a priority issue.
Action. Forestry Canada has been active in developing and reinforcing its role in forest biotechnology research. The department has strengthened its in-house program in plant biotechnology and in biotechnology for pest control, and is leading or actively participating in a number of biotechnology networks and special agreements. Forestry Canada in 1990 will assume leadership of the BIOFOR network and will be operating an expanded biotechnology research program through increased funding from the National Biotechnology Strategy. Finalization of the strategic plan for biotechnology research was delayed pending formalization of these new arrangements, but will now proceed as rapidly as possible, with a target of early summer 1990 for publication.

Recommendation 12. Forestry Canada should complete and widely distribute its strategic plan for spruce budworm research as soon as possible.

FC Response. Forestry Canada agrees with this recommendation and will complete this plan as soon as possible.

Action. A first draft of the strategic plan has been prepared but the document will require additional work to fully reflect Forestry Canada's overall strategic priorities in research before it is ready for publication. In the meantime, Forestry Canada is committed to the continuation of a strong spruce budworm research program.

Recommendation 13. Forestry Canada should make greater use of economics criteria in research evaluation and planning, and developing improved methods for analyzing forest land management options.

FC Response. Forestry Canada agrees in principle with this recommendation, and will attempt to make more use of economic cost-benefit criteria in its research planning and evaluation activities.

Action. The Department's annual work planning process has been modified to better identify and track the cost of its research programs. Additionally, the plan will identify the client agencies that are expected to use the results, and the general nature and magnitude of benefits. One of the major objectives of the Research Program Assessment Process, which was initiated in 1988, is to evaluate the level, relevance, and socio-economic benefits of the outputs from each of Forestry Canada's major research program areas. All research program areas are scheduled to be assessed in this manner over a four-year cycle. More quantitative economic costbenefit analyses are also being done for specific program areas whenever research results and other circumstances make this feasible and appropriate.

\section{Appendix IV \\ Forestry Research Advisory Council of Canada \\ Terms of Reference}

The Forestry Research Advisory Council of Canada provides the Deputy Minister, Forestry Canada, with sound, independent information and advice concerning the state of forestry research in Canada, particularly as regards the research programs of Forestry Canada.

The goal of the Council is to promote effective forest protection and management on a scientific basis in order to improve Canada's forest resources, particularly the economic wood supply, in relation to present and future needs.
To this end, the Council provides a national focus for forestry research coordination, identifies broad research needs and priorities and reviews research activities to obtain a balanced response to national and regional needs.

\section{Functions}

More specifically, the Council's functions are to:

1. Review and participate in the development of Forestry Canada's research policies and strategic plans. 
2. Examine broad research priorities in relation to policies and strategic plans.

3. Review the regional distribution and orientation of Forestry Canada's research programs and funding.

4. Review and advise on collaborative programs with forest management organizations and on the role of Forestry Canada in the context of other related research agencies.

5. Review and advise on technology transfer, i.e., the development and application of new and existing knowledge.

6. Review and advise on effective means of communication and information exchange between Forestry and other regional, provincial and national research and research advisory bodies.

7. Make recommendations to the Deputy Minister on any or all of the above, either on its own initiative or at the request of the Deputy Minister.

8. Prepare for consideration by the Canadian Council of Forest Ministers, an annual review and synthesis of the priorities and concerns of the senior provincial and territorial research advisory bodies.

\section{Membership}

Members shall be selected from the following groups:

\section{Industry}

Provinces

Universities

Canadian Pulp \& Paper Assoc.

Canadian Inst. of Forestry

\section{5}

5 (B.C., Ont. \& Que. are permanent members)
2

1

$\frac{1}{14}$

\section{Ex Officio}

Forestry Canada

1

The selection process shall pay due regard to the need for a wide range of experience and skills, regional balance and demonstrated leadership. Appointments will be made for periods of three years by the Deputy Minister in consultation with the three main participating groups. A Chairman and a Vice-Chairman will be selected by the Deputy Minister, the Vice-Chairman will not necessarily succeed to the Chairmanship.

\section{Method of Operation}

The Council shall meet no less than twice a year, at the call of the Chairman.

It will investigate and advise on specific topics chosen by the Council itself or at the request of the Deputy Minister.

The Council shall be empowered to establish subcommittees and make assignments to its members.

\section{Budget}

An annual budget will be provided by Forestry Canada to care for travel and related costs of meetings.

\section{Reporting Relationship} Minister.

The Council will make an annual report to the Deputy

\author{
Jean Claude Mercier \\ Deputy Minister \\ Forestry Canada \\ March, 1990
}

\section{YOUR FOREST... YOUR RESPONSIBILITY}

